\title{
Deep Norden: Highlights of the lithospheric structure of Northern Europe, Iceland, and Greenland
}

Department of Geography and Geology, University of Copenhagen, DK-1350 Copenhagen K, Denmark. E-mail: irina@geol.ku.dk

We present a review of geophysical models of the continental lithosphere of Norden, which includes the Nordic countries (Denmark, Iceland, Finland, Norway, Sweden), Greenland, and the adjacent regions of the neighbouring countries. The structure of the crust and the lithospheric mantle reflects the geologic evolution of Norden from Precambrian terrane accretion and subduction within the Baltic Shield and Greenland to Phanerozoic rifting, volcanism, magmatic crust formation, subduction and continent-continent collision at the edges of the cratons and at the plate boundaries. The proposed existence of a mantle plume below Iceland has not been uniquely demonstrated by the available seismic evidence. Its connection to the break-up of the North Atlantic Ocean c. 65 My ago is uncertain, but the $>30 \mathrm{~km}$ thick crust in the strait between Iceland and Greenland may indicate the track of the plume. Using the results from seismic (reflection and refraction profiles, $P$ - and S-wave, body-wave and surface-wave tomography), thermal, gravity, and petrologic studies, we review the structure of the crust and the lithospheric mantle of Norden and propose an integrated model of physical properties of the lithosphere of the region, including maps of lateral variation in crustal and lithospheric thicknesses and compositional variation in the lithospheric mantle.

\section{Tectonic setting}

The continental crust of Norden is chiefly of Precambrian age (Gaal and Gorbatschev, 1987), with large parts covered by Phanerozoic sedimentary sequences (the continental shelves and the North Sea area) and ice (Greenland). The topography is highly variable (Figure 1) with generally high topography in Norway (reaching c. 2,500 $\mathrm{m}$ in the peaks), gradually leveling eastwards to a constant value of a few hundred meters in the Precambrian shield of Sweden, Finland and Russian Kola-Karelia, and decreasing to about sea level in the sediment-covered areas around Denmark, the North Sea and Baltic Sea, and the continental shelves. The young ( $<16 \mathrm{Ma}$, Björnsson et al., 2005) crust around the oceanic spreading centre in Iceland is, surprisingly, above sea level, attaining surface elevations of up to $1,000 \mathrm{~m}$. In the central parts of Greenland, where the ice cap reaches an elevation of c. 3,500 m above sea level, the bedrock topography is some hundred meters below sea level (Bamber et al., 2001), in contrast to the slightly elevated topography at the western coast and the generally high elevation (up to c. 2,500 m) along the eastern margin, where the topography is similar to the other side of the North Atlantic, in Norway. Negative bedrock topography in central Greenland may be explained by isostatic balancing of the load of the ice cap; the thickest ice sheet is found in those parts of Greenland where the bedrock topography is most depressed.

Due to the ice cover, the crust in Greenland is known only in a narrow rim at along the coast. Where it outcrops, it is mainly of Proterozoic age (Kalsbeek, 1993), although much of southern Greenland is Archaean and the Itsaq gneiss complex of southern West Greenland hosts some of the oldest rocks on Earth (c. 3.9 Ga, Baadsgaard, 1973; Nutman et al., 1993). Kimberlite dikes and pipes are also found in parts of western Greenland. The eastern parts of Greenland have been subject to the Caledonian orogeny, similar to the Norwegian side of the North Atlantic Ocean. The margins of Greenland and Norway were rifted apart during continental break-up and opening of the North Atlantic Ocean at about $65 \mathrm{Ma}$.

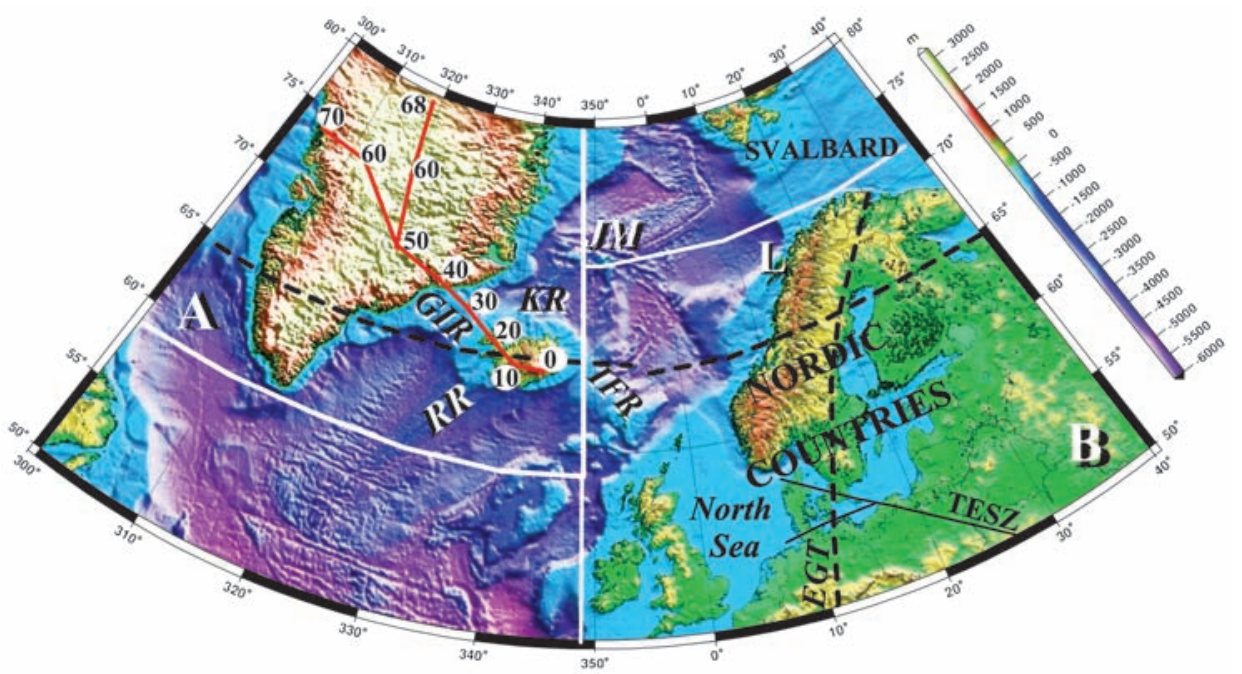

Figure 1 Topography and bathymetry of Norden (based on ETOPO2 data, NOAA, 2001). Dashed black lines-locations of 2 profiles (the European Geotraverse EGT and along $65^{\circ} \mathrm{N}$ ) discussed in the text. White boxes labeled $A$ and $B$-outlines of regions shown in other figures. Red lines-proposed tracks of Iceland hotspot (numbers-ages in My) (after Forsyth et al., 1986 and Lawver and Müller, 1994). Thin line-Trans-European Suture Zone (TESZ), which separates Precambrian East European craton from Phanerozoic Europe. Abbreviations: GIR-Greenland-Iceland ridge, IFR-Iceland-Faeroe ridge, KR-Kolbeinsey Ridge, $R R-R e y k j a n e s$ ridge, JM-Jan Mayen microcontinent, L-Archaean Lofoten block. 
The Baltic Fennoscandian Shield in Norden includes an Archaean block (chiefly 2.9-2.7 Ga), located in the Kola-Karelian provinces of Finland and Russia, to which a series of terranes (Svecofennia) were accreted during the early Proterozoic (2.0-1.8 Ga) (Gaal and Gorbatschev, 1987). The southern part of the Baltic Shield has been significantly affected by the Sveconorwegian orogeny $(1.1-0.9 \mathrm{Ga})$. The Caledonian orogeny $(500-400 \mathrm{Ma})$ along the present western margin of the Baltic Shield and the eastern margin of Greenland resulted from collision of two main plates of Baltica and Laurentia. In the North Sea area, a micro-continent or a series of accreted terranes (Avalonia) formed a triple junction with Baltica and Laurentia (MONA LISA Working Group, 1997). On both sides of the North Atlantic, the Caledonian structures are identified in an up-to $200 \mathrm{~km}$ wide onshore zone. Further, on both sides of the North Atlantic, a 100-600 km wide continental shelf separates the land areas from the deep ocean. This shelf probably was also affected by the Caledonian tectonic events (Olesen et al., 2002).

The major geological boundary in Europe, the Trans-European Suture Zone (TESZ) marks the southwestern margin of the Proterozoic crustal domains of the Baltic Shield and the East European Platform. It came into existence during the accretion of a series of terranes during the Caledonian and the Variscan (430-280 Ma) orogenies (cf. Thybo et al., 2002, and references therein). The southwestern, Proterozoic and Palaeozoic part of Norden subsided during the late Palaeozoic and Mesozoic to form the North Sea basins. This basin formation followed intensive rifting episodes at, for example, the economically important Central Graben in the North Sea and the Oslo Graben (Ramberg and Smithson, 1975; Olsen, 1995).

The youngest $(<16 \mathrm{Ma})$ onshore crust in Norden is located in Iceland, although Caledonian and older ages have been reported for the recycled crust (Korenaga and Kelemen, 2000). One of two major positive geoid anomalies on Earth $(+60 \mathrm{~m})$ peaks over Iceland. The positive free air gravity values and the elevated surface topography indicate significant dynamic support from the mantle in a wide zone around Iceland, which is situated above sea level at the intersection of two major tectonic structures: the oceanic spreading zone of the North Atlantic Ocean (that is the boundary between the American and European plates, diverging at the rate of $2 \mathrm{~cm} / \mathrm{y}$ ) and the Greenland-Iceland-Faeroe ridge of shallow bathymetry (Figure 1) and thick $(25-35 \mathrm{~km})$ oceanic crust (Figure 2). The ridge, transversing the North Atlantic, is interpreted either as a track of a semistationary (with respect to plate boundary) mantle plume (Lundin and Dore, 2005) or as major melting anomaly associated with a persistent volcanism centered at c. $65^{\circ} \mathrm{N}$ at the Mid-Atlantic ridge (Boutilier and Keen, 1999). In Iceland, the spreading ridge migrates eastwards; it was proposed that over the past $17 \mathrm{Ma}$ (and perhaps as long as 26 Ma) spreading in Iceland has occurred along two parallel ridges (Foulger and Anderson, 2005). Tertiary flood basalts and shield volcanoes in the axial rift zone of Iceland are composed of primitive olivine-tholeiites generated at 20-40 km depth (Schiellerup, 1995). Icelandic basalts have a distinctive depleted component interpreted to be recycled oceanic crust (Chauvel and Hemond, 2002) and an iron-enriched component derived either from a chiefly eclogitic source (Foulger et al., 2005) or from an ancient OIB seamount structure (McKenzie at al., 2004). The source may also contain fragments of Caledonian and older continental lithosphere (Korenaga and Kelemen, 2000), e.g. the Jan Mayen microcontinent that separated from East Greenland c. $44 \mathrm{Ma}$ or continental lithosphere delaminated during the opening of the North Atlantic.

\section{Crustal thickness}

The crustal thickness in the Nordic area is relatively well known, in particular in the Baltic Shield and in Iceland, from a series of controlled source seismological surveys (Figure 2). The thickest crust $(>60 \mathrm{~km})$ is observed in a localized area in the Archean and Proterozoic terranes of south-central Finland (Tiira et al., 2006). The Archaean Kola province and most of the Svecofennian province

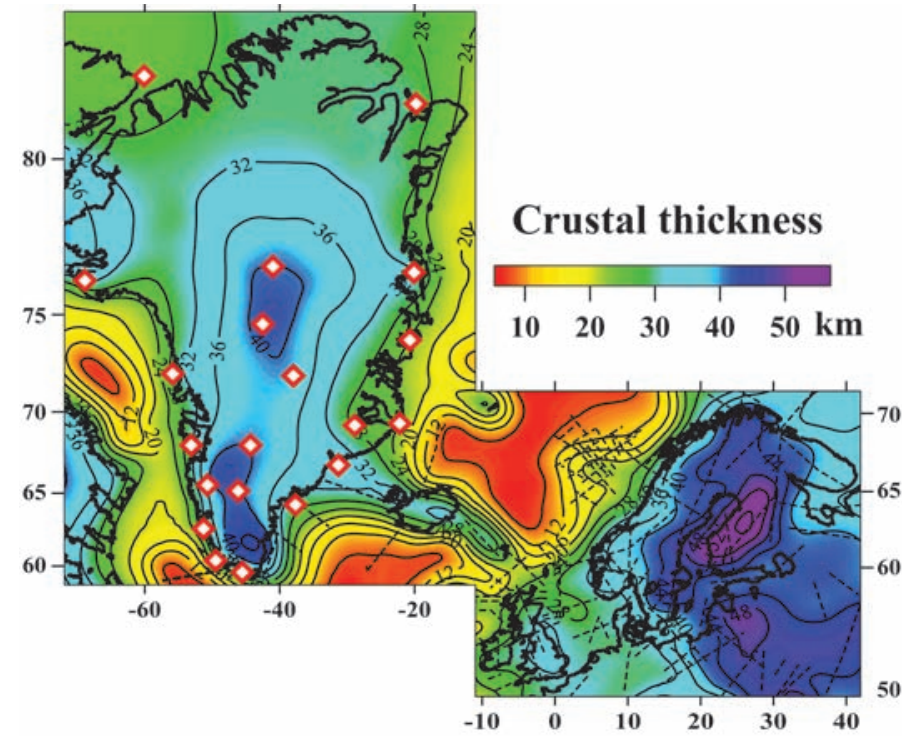

Figure 2 Crustal thickness in Northern Europe, Iceland and Greenland (locations of major seismic profiles are shown by dashed lines, seismic stations in Greenland are shown by red diamonds). Data sources: see Artemieva et al. (2006) and Artemieva (2007) with additions from Korsman et al. (1999), Tsikalas et al. (2005), Hyvonen et al. (2007), Kelly et al. (2007), and Olsson et al. (2007) for Northern Europe; Kumar et al. (2007), Dahl-Jensen et al. (1998, 2003), Holbrook et al. (2001), and Chian and Louden (1992) for Greenland; Bott and Gunnarsson (1980) for Iceland-Faeroe ridge and Kodaira et al. (1998) for the Jan Mayen microcontinent.

have crustal thicknesses of $40-50 \mathrm{~km}$, similar to most of the East European Platform further to the southeast. The Caledonian deformed belt is characterized by a relatively thin crust $(30-36 \mathrm{~km})$, although values of c. $40 \mathrm{~km}$ have been reported for the southern part of Norway (Svenningsen et al., 2007). Most of this region has further been subject to the effects of ocean break-up along the Norwegian coast and to intensive rifting episodes with related crustal thinning in the North Sea area (Beach, 1986; Olsen, 1995). The TESZ marks a sharp transition from a thick (typically $>40 \mathrm{~km}$ ) Precambrian to a thin $(28-32 \mathrm{~km})$ Phanerozoic crust, although the Precambrian crust in the Tornquist Fan area of the North Sea basin has been significantly thinned (to c. $25-30 \mathrm{~km}$ ) in-between thicker, more stable blocks during Paleozoic-Mesozoic rifting and basin formation (Thybo, 1997).

A substantial number of seismic and gravity studies have challenged estimates of the crustal thickness in Iceland. Two competing points of view exist: thin crust and thick crust (see e.g., Foulger et al., 2005 for overview). Both interpretations are based chiefly on similar or the same seismic data, which indicate a gradual increase in Vp seismic velocity from $6.5-7.0 \mathrm{~km} / \mathrm{s}$ in the oceanic Layer 3 at depths above $10-20 \mathrm{~km}$ to $\mathrm{Vp} \sim 7.0-7.6 \mathrm{~km} / \mathrm{s}$ in Layer 4, that extends down to at least $60 \mathrm{~km}$ depth (Angenheistr et al., 1980). The major difference between "thin" and "thick" crustal models is in petrological and tectonic interpretations of Layer 4. In the thin-crust model, layer 4 is interpreted as anomalous peridotite mantle with a melt content of c. 2\% (Schmeling, 1985). The thick-crust model interprets Layer 4 as gabbroic "lower crust" with some lenses of melt. Note that in both models partial melts are expected below 10-20 km depth.

According to the thin-crust model (Palmason, 1971), crustal thickness is $10-15 \mathrm{~km}$ under the main rifting axes increasing to c. 25 $\mathrm{km}$ in the oldest, Tertiary, eastern and western parts of Iceland. Thin crust is supported by electromagnetic studies (Björnsson et al., 2005 ), which indicate the presence of electrical conductor at $<15 \mathrm{~km}$ depth below the active rift zones and at $>25 \mathrm{~km}$ depth in Tertiary areas. The thick-crust model interprets the crust to be $35-40 \mathrm{~km}$ in 
central Iceland thinning to $30 \mathrm{~km}$ in the eastern and northern areas and to $20-25 \mathrm{~km}$ in the western and southern areas. This model is supported by the presence of deep seismic reflectors at 20-40 km depth (Gebrande et al., 1980; Bjarnason et al., 1993), which are commonly interpreted as the Moho (Menke and Levin, 1994; Staples et al., 1997; Darbyshire et al., 2000). However, the reflectors are fragmented and cannot be interpolated into a continuous interface (Kaban et al., 2002).

Gravity modeling (Darbyshire et al., 2000; Kaban et al., 2002; Fedorova et al., 2005) fails to discriminate between "thin" and "thick" crustal models: both crustal models can fit the data and explain the major Bouguer gravity low centered in east-central Iceland (Eysteinsson and Gunmarsson, 1995). They estimate the density of Layer 4 to be in the range of $3,030-3,150 \mathrm{~kg} / \mathrm{m}^{3}$, i.e., intermediate between the typical oceanic crustal densities $\left(2,970 \mathrm{~kg} / \mathrm{m}^{3}\right)$ and the typical uppermost mantle densities $\left(3,300 \mathrm{~kg} / \mathrm{m}^{3}\right)$. Thin-crust model implies hot lithosphere with a high percent of melt in Layer 4, not observed in seismic studies. In contrast, thick-crust model requires low mantle temperatures to keep a $20 \mathrm{~km}$ thick gabbroic Layer 4 below the gabbro solidus (Menke and Levin, 1994). Low temperatures are consistent with regional off-shore heat flow observations which do not show any heat flow anomaly (Stein and Stein, 2003). However, they contradict on-shore observations of a high temperature gradient in Iceland and temperature estimates based on the maximal earthquake hypocentral depths (Bjarnason et al., 1994).

The crust between Greenland, Iceland, and Faeroe Islands is surprisingly thick for oceanic crust (normal oceanic crust north and south of Iceland is $8-10 \mathrm{~km}$ thick). The Iceland-Faeroe ridge has a clear seismic Moho at a $30-35 \mathrm{~km}$ depth, and a similar crustal thickness was determined for the Greenland-Iceland ridge (Bott and Gunnarsson, 1980; Staples et al., 1997; Holbrook et al., 2001). The symmetric crustal structure to the west and east of Iceland has been used to argue against the plume origin of Iceland, unless it was semistationary with respect to the plate boundary (Lundin and Dore, 2005).

The crustal structure of Greenland is relatively poorly known. A recent broad band seismological experiment, GLATIS (DahlJensen et al., 2003; Kumar et al., 2007) has provided estimates of the crustal thickness at about 20 locations by receiver function (RF) analysis. Most of the seismic stations were deployed close to the coast, but some of locations are within the central part of the ice cover (Figure 2). Further, some refraction seismic experiments provide profiles of crustal structure in the western and southeastern offshore parts of Greenland (Chian and Louden, 1992; Dahl-Jensen et al., 1998; Holbrook et al., 2001).

All onshore determinations of crustal thickness in Greenland are based on receiver function analysis of the depth to a seismic converter. They indicate that the crust below central Greenland is 40-45 $\mathrm{km}$ thick and that it thins towards the coasts, where values of some $30 \mathrm{~km}$ are estimated. It is remarkable that the highest bedrock elevation in Greenland (c. $2.0 \mathrm{~km}$ along the eastern coast) is apparently underlain by a relatively thin crust (c. $25-30 \mathrm{~km}$ ). However, some of the values for eastern Greenland have been determined at locations close to the areas with extended continental crust. Therefore, it cannot be excluded that a high-velocity layer in the lower crust has not been identified as a part of the crust in the RF analysis. This is, in particular, very likely in the near-shore areas with extended crust, as exemplified by the significant discrepancy in the values reported by different groups: while the receiver function analysis gives values of around $30 \mathrm{~km}$, seismic refraction profiles within a distance of less than $50 \mathrm{~km}$ from the shore indicate crustal thicknesses of c. 40-45 $\mathrm{km}$ along both the southwestern (e.g., Dahl-Jensen et al., 1998) and the eastern coasts (Chian and Louden, 1992). Along the coast of the North Atlantic Ocean, the lowest crust has extremely high seismic velocity $(7.4-7.6 \mathrm{~km} / \mathrm{s}$ which may be related to magmatic underplating, Dahl-Jensen et al., 1998) such that the strongest seismic converter may well be the transition from the middle to the lower crust, and not the Moho.

\section{Seismic structure of the upper mantle}

Interpretations of seismic reflection/refraction profiles, regional and global upper mantle seismic tomography, thermal, gravity, electromagnetic, xenolith, and elastic data (Artemieva et al., 2006 and references therein) provide an extensive database on the lithospheric structure of the Baltic Shield, whereas the information on the deep structure of Iceland and, in particular, Greenland remains sparse and, in some cases, controversial (e.g., Ritsema and Allen, 2003; Darbyshire et al., 2004; Foulger et al., 2005). In this situation, global tomographic models provide a means for a comparison of the deep structure of the upper mantle of the entire Norden, illustrated here by the variation in seismic S-wave velocity at a depth of c. $150 \mathrm{~km}$ (Figure 3). The resolution for the body-wave seismic tomography model is at least $500 \mathrm{~km}$ horizontally and no better than $50-100 \mathrm{~km}$ vertically.

At $150 \mathrm{~km}$ depth, high S-wave velocity $(>4.6 \mathrm{~km} / \mathrm{s})$ is observed in the Precambrian terranes of the East European Craton (which outcrops in the Baltic Shield) and Greenland, where lithospheric keels generally extend down to at least $200 \mathrm{~km}$ depth (Artemieva and Mooney, 2001). Areas close to the cratonic edges have smaller velocity associated with the transition from lithospheric to sublithospheric mantle at c. $120-150 \mathrm{~km}$ depth. Within the regions with Precambrian crust in Northern Europe, the rifted area of the North Sea, where the lithospheric thickness is c. $100 \mathrm{~km}$, shows a strong low velocity anomaly, with velocities smaller than $4.5 \mathrm{~km} / \mathrm{s}$. The transition from the cratonic to the Phanerozoic lithosphere in Northern Europe is marked by a pronounced decrease in seismic velocities at $150 \mathrm{~km}$ depth across the TESZ (Zielhuis and Nolet, 1994).

Like for the Precambrian Baltic Shield, high seismic velocities $(>4.6 \mathrm{~km} / \mathrm{s})$ are observed for Greenland (Figure 3). Similar values have been calculated in surface-wave tomography models (Shapiro and Ritzwoller, 2002; Darbyshire et al., 2004), although their lateral resolution is lower than the resolution of the body-wave model (Grand, 2002). Seismic velocities in the tomography models (in particular, for surface waves) are sensitive to the corrections for the crustal structure, which is poorly known for the inland parts of Greenland. Thus, the velocity map for Greenland should be treated with some caution. The coastal areas of Greenland with extended crust towards the North Atlantic Ocean have low upper mantle seismic velocities. Similarly, low velocities are observed in the southernmost part of Greenland, which also may be an effect of the proximal continent to ocean transition. Part of the low-velocity anomaly

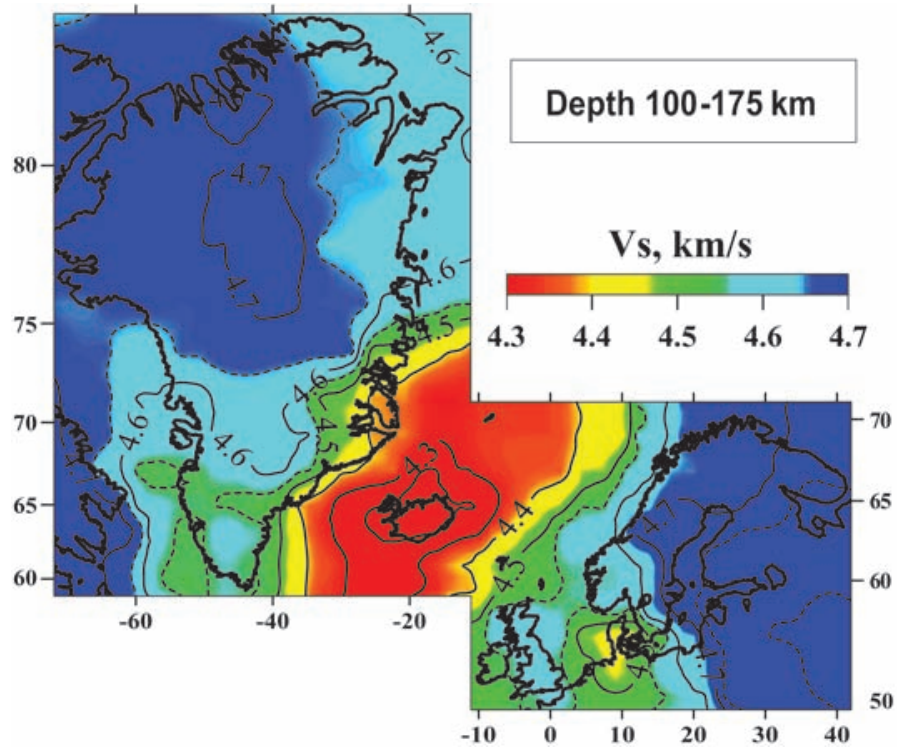

Figure 3 S-wave velocities in Northern Europe, Iceland and Greenland at 100-175 km depth based on the global body-wave seismic tomography model of Grand (2002). 
at the southeastern coast can result from the smearing effect of the strong low-velocity anomaly around Iceland (Figure 3).

A layer below a depth of $100 \mathrm{~km}$ with slightly reduced seismic velocity has been identified by surface wave interpretation in the Baltic Shield and in Greenland (Bruneton et al., 2004; Darbyshire et al., 2004), thus confirming global analysis of body waves (Thybo and Perchuc, 1997). A recent interpretation by S-receiver function analysis of data from Greenland, Iceland and the North Atlantic shows a seismic interface at a depth of c. $100 \mathrm{~km}$ throughout the region (Kumar et al., 2006). Although these authors interpret this converter as the base of the lithosphere, it coincides with the top of the global, reduced-velocity zone in the upper mantle and in areas with a $>200 \mathrm{~km}$ thick lithosphere this converter represents an intralithospheric feature. In Precambrian areas, typical seismic velocity anomalies above and below this layer are $\delta \mathrm{Vs} \sim+1+3 \%$ (with respect to the global continental reference model ak135), while within the layer they drop to $\delta \mathrm{Vs} \sim 0+2 \%$. In the high-velocity lithospheric mantle of the Baltic Shield, this layer is about $60 \mathrm{~km}$ thick with its thickness decreasing towards the oldest parts of the shield, generally with low heat flow. The nature of the reduced-velocity zone is still debated. Possible interpretations include: (a) high homologous mantle temperatures (c. $0.85 * \mathrm{Tm}$, where $\mathrm{Tm}$ is wet solidus temperature) (Thybo, 2006) at which a sharp change in rheology and elastic properties of olivine-rich rocks (with a few percent drop in seismic velocities) is expected from laboratory experiments (Sato et al., 1989), or (b) petrologic heterogeneity in the lithosphere, e.g., associated with regional metasomatism (Artemieva, 2003). Note that neither thermal models (Artemieva, 2003), nor petrologic data on mantle-derived xenoliths (Kukkonen and Peltonen, 1999) require the presence of asthenospheric material in the upper $250-300 \mathrm{~km}$ beneath the Archean-early Proterozoic part of the Baltic Shield.

Surface wave tomography indicates that the upper mantle of Iceland exhibits a significant, isolated (c. 1,000 km in diameter), low S-wave velocity anomaly, which may extend to depths of at least 600 $\mathrm{km}$ (Figure 4a). This observation, together with a similar anomaly in the body-wave tomography model (Bijwaard and Spakman, 1999), where the P-wave anomaly persists below the transition zone, has been interpreted by some authors as evidence for a mantle plume (e.g., Bijwaard and Spakman, 1999; Ritsema and Allen, 2003). The observed S- and P-wave velocity anomaly (c. 5-10\%) in the shallow mantle suggests a temperature anomaly of c. $50-100{ }^{\circ} \mathrm{C}$ and $<1 \%$ of melt (perhaps as little as $<0.1 \%$ ) (Foulger et al., 2005 and references therein). Receiver function analysis of seismic data from Iceland (Vinnik et al., 2005) contributes to the on-going debate on the very existence of the Iceland plume (Foulger and Anderson, 2005) and challenges the conclusion of its existence (Figure 4b): it reveals the presence of a low-velocity zone in the shallow mantle only (centered at a depth of $100 \mathrm{~km}$ ) and the normal thickness of the transition zone (a weak depression of the $410 \mathrm{~km}$ discontinuity can be explained by a c. $50^{\circ} \mathrm{C}$ thermal anomaly, Presnall, 1995).

Courtillot et al. (2003) have proposed 5 criteria considered to characterize plumes (hot-spot track, large igneous province at one of the ends, high buoyancy flux, high ${ }^{3} \mathrm{He} /{ }^{4} \mathrm{He}$ ratio, and low seismic velocities in the mantle), and concluded that Iceland is a major hotspot, which satisfies at least 4 of the criteria. Anderson (2005) extended the number of "plume-criteria" to 12 (including the parameters which characterize seismic structure of the entire mantle and its thermal state) and concluded that Iceland equals on "plume" and "plate tectonics" scores, the major plume evidences being a lowvelocity anomaly in the upper $400 \mathrm{~km}$ and ${ }^{3} \mathrm{He} /{ }^{4} \mathrm{He}$ ratios among the highest on Earth. We suggest that laboratory simulations of plume generation, evolution, and death in thermo-chemical convection (Davaille and Vatteville, 2005) provide an elegant resolution of the debate on the existence of the Iceland plume: in a dying plume, negative compositional buoyancy is no longer compensated by a positive thermal buoyancy, resulting in a downward flow along still hotter-than-normal "plume channel" seen in seismic tomography models for Iceland. Further, dying "plumes start disappearing from the bottom up, sometimes even before reaching the upper boundary", and "they finally fade away by thermal diffusion. This sequence of
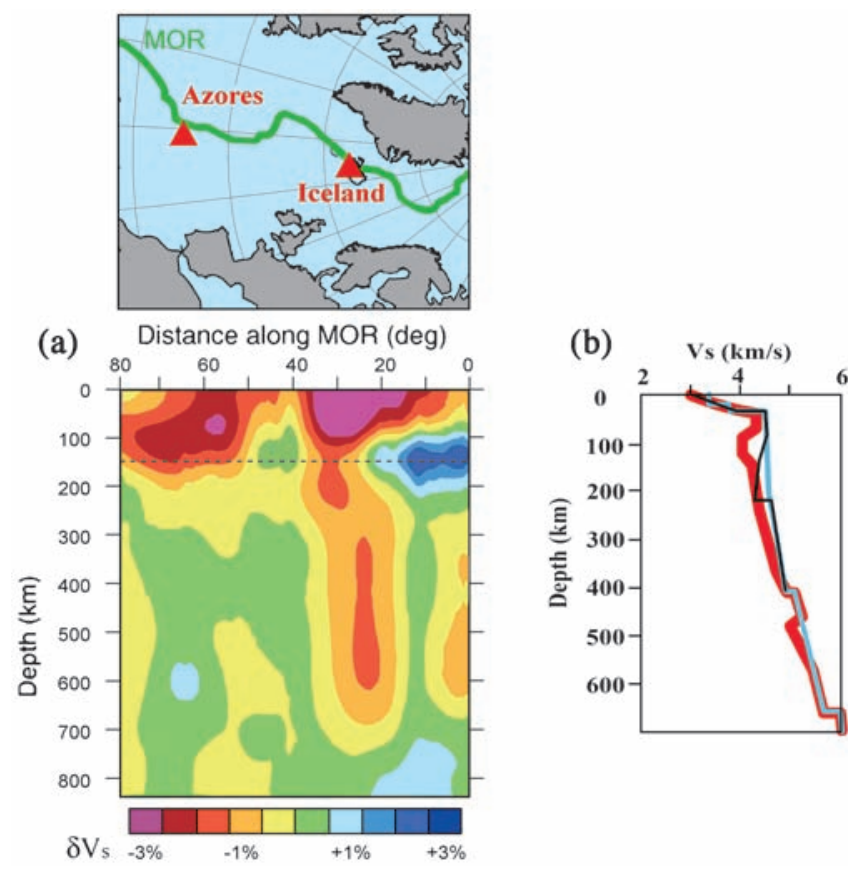

Figure 4 (a) Seismic tomographic profile along the Mid-Atlantic Ridge (MOR) (after Ritsema \& Allen, 2003). Note the strong negative relative velocity anomaly around Iceland extending down to $660 \mathrm{~km}$ and interpreted as the signature of a mantle plume. (b) Seismic velocity model based on calculation of Receiver Functions for a station on Iceland (red line, after Vinnik et al., 2005). Note that, as compared to the velocity profile in (a), a velocity anomaly (red line) with respect to the global continental velocity profile (IASP91 model, blue line) is observed only down to a $400 \mathrm{~km}$ depth, with its amplitude decreasing with depth (global velocity model PREM is shown by black line). The receiver function interpretation shows seismic converters surrounding the low velocity zone below $100 \mathrm{~km}$ and at the 410 and $660 \mathrm{~km}$ discontinuities.

events shows that time-dependence is a key-factor when interpreting present-day tomographic images of mantle upwellings. In particular, it could be erroneous to identify the depth of a present-day slow seismic anomaly with the depth of its origin, or to interpret the absence of a long tail as the absence of a plume." (Davaille and Vatteville, 2005).

Global analyses of mantle-derived xenoliths indicate significant lateral and vertical compositional heterogeneity of the upper mantle, which reflects its tectonic and geological evolution. Since seismic velocities are sensitive to temperature of the mantle rocks (e.g. Jackson, 2000), variations in the thermal regime of the upper mantle can effectively mask velocity anomalies of a non-thermal origin caused by variations in composition, volatiles, as well as anelasticity, variations in grain size, and anisotropy. The $\mathrm{Vp} / \mathrm{Vs}$ ratio is more sensitive to compositional than to thermal effects (Lee, 2003) and thus provides valuable information on the structure and compositional variations in the upper mantle (Figure 5). Since no high-resolution Pwave velocity model is available for Greenland, we limit the discussion to the Baltic Shield and the adjacent regions. Low values of $\mathrm{Vp} / \mathrm{Vs}$ ratio indicate that a highly depleted (primarily in the basaltic component) mantle in the central part of the Baltic Shield, identified by geochemical studies of mantle-derived xenoliths (Peltonen and Brugmann, 2006), extends well into the Precambrian East European Platform. Gravity (Kaban et al., 2003) and buoyancy (Artemieva, 2003) modeling provide further evidence that lithospheric mantle of the Precambrian Europe is low-dense and thus depleted. The transition to the fertile Phanerozoic mantle of western Europe is marked by a sharp change to higher $\mathrm{Vp} / \mathrm{Vs}$ values along the TESZ. The rifted areas of northern Europe with Precambrian crust, including the North Sea area and the Oslo Rift, show high $\mathrm{Vp} / \mathrm{Vs}$ values indicative of a fertile mantle composition at sublithospheric depths. 


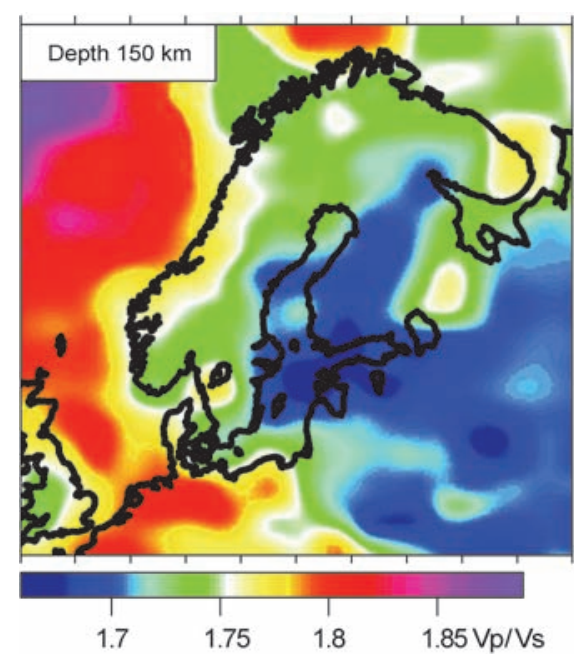

Figure 5 Compositional heterogeneity in the lithospheric mantle of Northern Europe, based on the Vp/Vs ratio. (Modified after Artemieva et al., 2006 and calculated using the $S$-wave surfacewave tomography model of Shapiro \& Ritzwoller, 2002 and $P$ wave body-wave tomography model of Bijwaard \& Spakman, 1999).

\section{Lithospheric thickness}

Geophysical data (primarily global seismic tomography models [e.g., Grand, 2002; Shapiro and Ritzwoller, 2002] and the global thermal model for the continents [Artemieva, 2006]) provide a unique possibility to construct a map of lithospheric thickness of Norden (Figure 6). Here, the base of seismic lithosphere is defined as a depth to $(2 \pm 0.5) \%$ velocity anomaly (with respect to continental reference model ak135 for continents and to global PREM model for oceans), while the base of thermal lithosphere is defined by a depth where mantle temperature reaches $1300{ }^{\circ} \mathrm{C}$. Figure 6 provides an integrated interpretation of seismic and thermal data, since thicknesses of seismic and thermal lithospheres may differ by as much as $40-50 \mathrm{~km}$ in stable continental regions (Jaupart and Mareschal, 1999). The resolution of the map is effectively controlled by the heat flow and seismic data coverage, which is dense for the Baltic Shield and more coarse for Greenland and the western North Atlantic Ocean.

Thick lithospheric keels, extending to at least a $250 \mathrm{~km}$ depth, have been identified with certainty beneath the Archaean provinces of the Baltic Shield and the central and southern parts of Greenland (Figure 6). The existence of a high-velocity upper mantle down to a depth of 200-250 km beneath much of the EEC, including most of the Baltic Shield, is supported by regional dispersion analyses of long-period Rayleigh waves (Calcagnile, 1991) and by large-scale $\mathrm{P}$ - and S-wave seismic tomography models. However, most surface wave models loose resolution at depths below c. $250 \mathrm{~km}$ and cannot provide reliable constraints on the mantle structure below this depth. Lithospheric geotherms constrained by surface heat flow measurements (Artemieva, 2003) and mantle-derived xenoliths from central Finland and the Arkhangelsk region of northern Russia (Kukkonen and Peltonen, 1999) confirm the presence of cold thick (>250 km) lithospheric keels in these provinces of Baltica.

The region of the anomalously thick crust in the Baltic Shield (Figure 2) is located at the suture between the Archean and early Proterozoic blocks which formed during Proterozoic accretion of the Svecofennian provinces to the Archean Karelian block (Korja et al., 1993). Within the resolution of the crustal and upper mantle models, it may mark the edge of the thickest lithospheric keel in the Baltic Shield (Figure 6). Most of the crustal roots were only recently identified beneath Proterozoic western Finland (Hyvonen et al., 2007; Olsson et al., 2007) and their tectonic origin remains unclear. The small size of the region (c. $500 \times 300 \mathrm{~km}$ ), where both the crust and the lithosphere have anomalous thicknesses, suggests that the crustal and lithospheric roots could have formed during the same tectonic event and that they may represent a unique preserved remnant of an ancient continent-continent or continent-ocean collision zone (Artemieva, 2006). The geographical distribution of midProterozoic rapakivi granite intrusions at the northwestern, western and southern sides of the region of thick lithosphere suggests that heat from the mantle has been deflected by the pre-existing lithospheric keel (Ballard and Pollack, 1987), causing magma generation along its rim. The deflection of heat from the mantle could further have assisted the survival of this thick keel during the mid-Proterozoic tectono-thermal activity in the region, which led to the formation of the Baltic/Bothnian Sea basin "embracing" the region of anomalously thick lithosphere in west-central Finland (Artemieva et al., 2006).

Similarly, both in central and southern Greenland the locations of the thickest crust and the thickest lithosphere are spatially close (Figures 2, 6). Due to the near-vertical wave propagation of teleseismic body-waves, the tomography model (Grand, 2002) used to constrain lithospheric thickness is only weakly sensitive to the crustal structure. Therefore, the spatial correlation between the maps of crustal and lithospheric thicknesses cannot be entirely attributed to incomplete crustal correction, although the lateral resolution of the seismic models is relatively low in Greenland. The thick lithospheric keel in the southern part of Greenland underlies Archean crust which outcrops along the coasts. The age of the lithosphere terrane in central Greenland is unknown. Here a $(2 \pm 0.5) \% \mathrm{~S}$-wave velocity anomaly based on both body-waves (Grand, 2002) and surface-waves (Shapiro and Ritzwoller, 2002) tomography models extends deeper than $250 \mathrm{~km}$. This observation may provide evidence for speculations about the age of the crust and lithospheric mantle in large parts of the ice-covered areas of Greenland. In southern Greenland, the northern margin of the region of anomalously thick crust and lithosphere (approximately at the latitude of the Arctic Circle) corresponds to the boundary between the Archean and early Proterozoic terranes, as evidenced by basement rock outcrops along the western and eastern coasts. While the thicknesses of the lithospheric keels in Greenland and the Baltic Shield are comparable, the maximum observed thickness of the crust is significantly smaller in Greenland than in the Baltic Shield (45-48 km versus $>60 \mathrm{~km}$ ). Nevertheless, the analogy to the Baltic Shield may indicate that the thickest crust and the thickest lithosphere in southern Greenland next to the Archaean-Proterozoic suture can be a remnant of late Proterozoic plate tectonic events. The situation in central Greenland is less clear

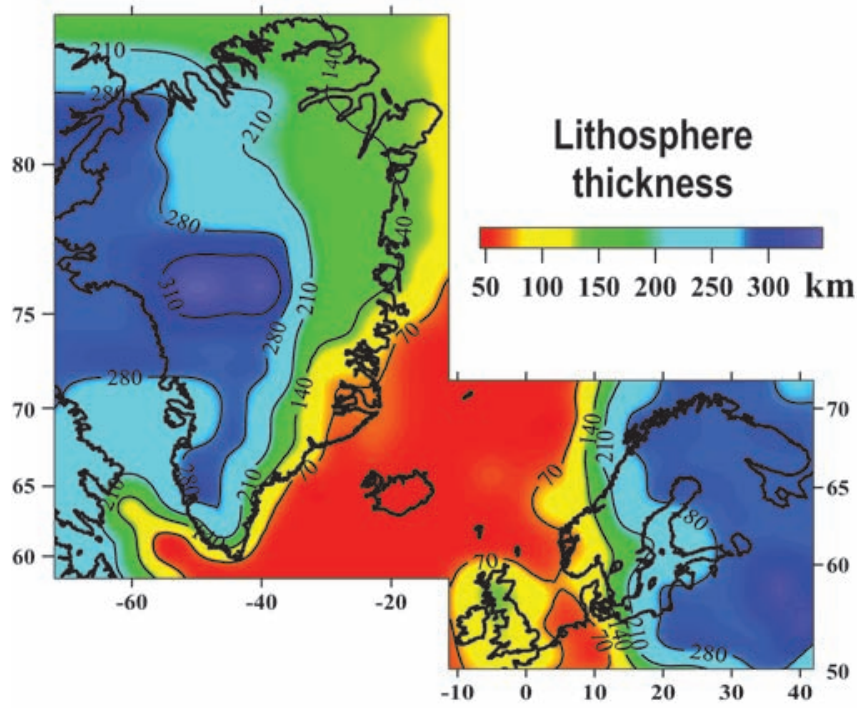

Figure 6 Lithosphere thickness in Norden, based on the global body-wave seismic tomography model of Grand (2002) and defined by a $(2 \pm 0.5) \% \delta V$ s anomaly with respect to the global continental reference model ak135 (Kennett et al., 1995) for the continents and with respect to PREM model for the oceans. 
due to the lack of data on crustal ages. Below Iceland, where lithosphere stretching along the Mid-Atlantic Ridge leads to partial melting at shallow depth and magmatic formation of new basaltic crust, lithospheric thickness is, as expected, small $(<50 \mathrm{~km})$.

\section{Profiles of lithospheric structure}

Two profiles of the lithospheric structure (Figures 7a, b) summarize the above overview and illustrate lateral and vertical variations in physical properties of the crust and upper mantle in Deep Norden. The North-to-South trending profile across the Nordic countries (Figure 7a) follows the northern part of the EGT (European GeoTraverse, Blundell et al., 1992) and crosses the following structures from north to south:

(a) a region with very thick crust and lithosphere in the Baltic Shield with significant variation in crustal thickness between different Precambrian blocks;

(b) dipping structures in the lithospheric mantle, recognized in regional seismic surveys in the Bothnian Gulf of the Baltic Sea and interpreted as Proterozoic subduction zones within the cratonic lithospheric mantle (BABEL Working Group, 1990;
Abramovitz et al., 1997). Magmatic intrusions within the TransScandinavian-Igneous Belt (TIB) may be associated with the same tectonic events or younger features. Dipping structures in the lithospheric mantle further south haves been interpreted as evidence for the Caledonian subduction at the southern margin of the craton (MONA LISA WG, 1997).

(c) The transition from the cratonic mantle of Baltica to Phanerozoic mantle of the European plate (at the TESZ) is marked by a sharp change in seismic velocities and $\mathrm{Vp} / \mathrm{Vs}$ ratio, which indicates a different composition of the mantle (primarily, the degree of mantle depletion). Gravity and buoyancy modeling require significantly different densities of Phanerozoic and Precambrian European lithospheric mantle and support this conclusion. The transition is further marked by a pronounced contrast in lithospheric and crustal thickness. The remnant of the Avalonia microcontinent is caught between the Baltica and the European plates; a dipping seismic reflector associated with the Paleozoic subduction zone marks its southern edge (near the Elbe River in Northern Germany) (Thybo, 1997).

The East-to-West trending profile along latitude $65^{\circ} \mathrm{N}$ (Figure 7b) illustrates variations in lithospheric structure from Greenland in the west, across the North Atlantic Ocean and Iceland, to the Baltic Shield in the east. Two zones of major contrasts in lithospheric struc-
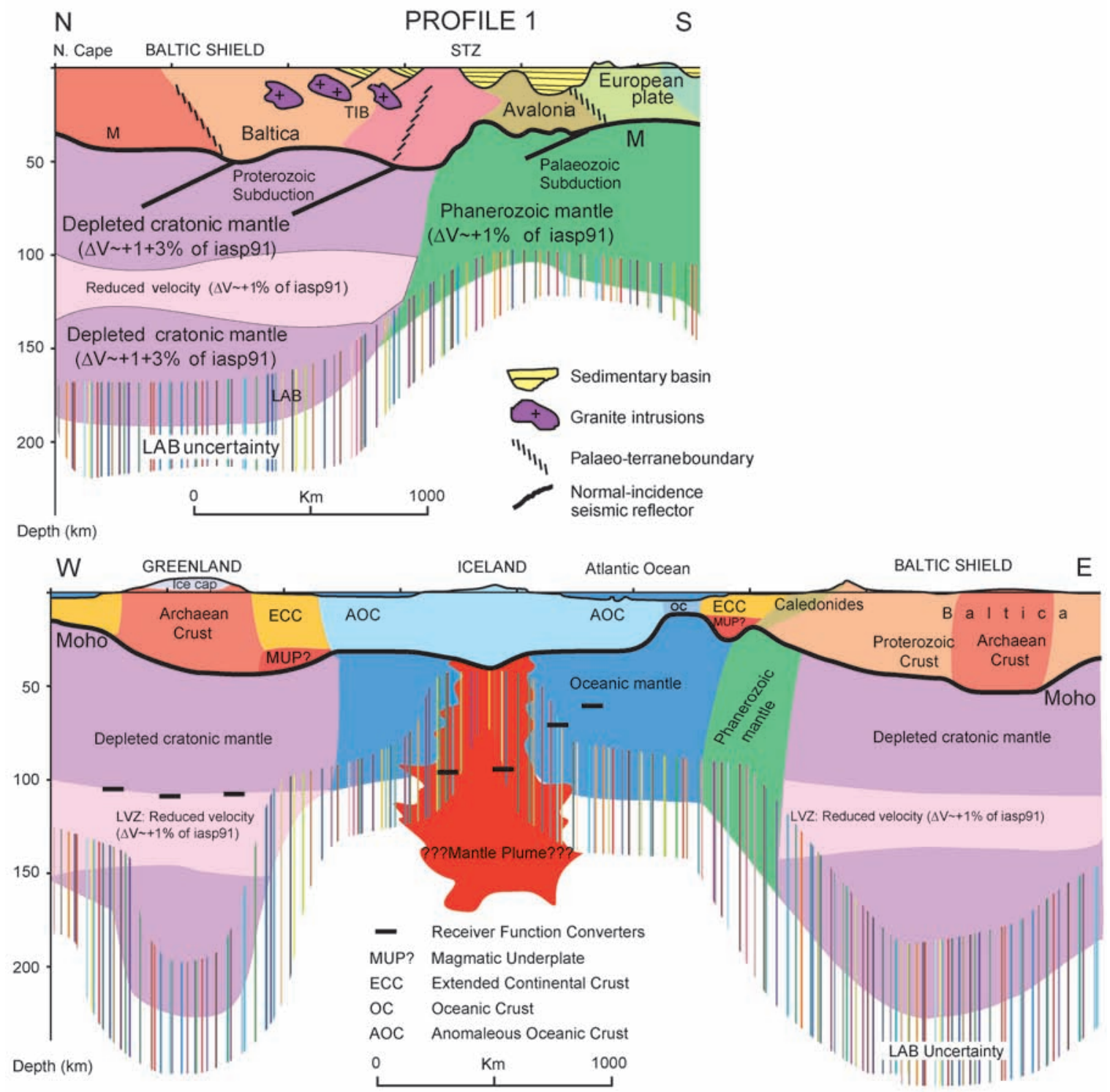

Figure 7 Two profiles through the lithosphere of Norden (see Figure 1a for locations): (a) N-S along the EGT profile (modified after Artemieva et al., 2006), (b) W-E along 65N latitude. The uncertainty of lithospheric thickness values is assessed to $\mathrm{c} .50 \mathrm{~km}$. Abbreviations: LAB - lithosphere-asthenosphere boundary, STZ-Sorgenfrei-Tornquist Zone (a part of the TESZ). 
ture are associated with the craton-ocean transitions at the western and eastern coasts of the North Atlantic.

(a) The thickest crust with Moho at a depth of $60 \mathrm{~km}$ has only been observed in the central Baltic Shield, whereas the available seismic data indicate more moderate values of crustal thickness in Greenland.

(b) The extended crust along the continental margins of the North Atlantic, at the edges of the Caledonides, is thinned to c. 28-35 $\mathrm{km}$ and is underlain by intermediate thickness lithosphere $(80-120 \mathrm{~km})$. Several geophysical experiments have demonstrated the presence of a high-velocity layer in the lowermost crust of these regions, which probably represents a layer of magmatic underplating (e.g., Staples et al., 1997; Dahl-Jensen et al., 1998; Holbrook et al., 2001; Raum et al., 2002) brought into existence during the break-up of the North Atlantic Ocean.

(c) A remarkable feature is the belt of thick (30-35 km) crust extending from Greenland through Iceland to the Faeroe Islands, across the North Atlantic Ocean. The origin of this belt of thick (oceanic?) crust with a thickness comparable to continental crust, is enigmatic. The oceanic magnetic lineaments are indistinct or non-existing in this zone. The formation of this thick crust may be related to the passage of the proposed Iceland plume (e.g., Holbrook, 2001), which, in this case, should be semistationary with respect to the diverging boundary between the American and the European plates (Lundin and Dore, 2002). The depth extent and width of the mantle plume are unknown (seismic images of the region are highly controversial), and new high-resolution seismological data acquisition is needed before a conclusion can be made concerning its existence.

\section{Conclusions}

We have compiled the available geophysical data on the structure of the crust and lithospheric mantle of Norden, which may be summarized as the followings:

- Thick lithosphere (>200 km) underlies the Precambrian parts of the continents. In some areas, regions with anomalously thick crust and very thick lithosphere $(>250 \mathrm{~km})$ spatially correlate and are close to the Archean-Proterozoic suture zones. These may represent remnants of Precambrian collisional tectonic events.

- Sub-Moho seismic reflectors observed in the cratonic mantle of Baltica may represent paleo-subduction features preserved since the Proterozoic.

- Passive margins of the North Atlantic Ocean are underlain by magmatic underplated material in the lowermost crust.

- The crust below Iceland and the Denmark Strait in the North Atlantic is unexpectedly thick and may be explained by the "plume passage" model.

- The topography of basement rocks in central Greenland is negative; the load of the ice cap in Greenland may be kept in isostatic balance by the buoyancy of the lithosphere.

- Seismic evidence for the presence of the proposed mantle plume beneath Iceland remains controversial and its presence has not yet been uniquely demonstrated.

\section{Acknowledgments}

The authors are indebted to S. Grand, N. Shapiro, M. Ritzwoller, and W. Spakman for providing their seismic tomographic models. Figure 1 was prepared by S.B. Lyngsie using the GMT software (by courtesy of Smith and Wessel). The paper has benefited from the constructive comments of S. Cloetingh and two anonymous reviewers.

\section{References}

Abramovitz, T., Thybo, H., and Berthelsen, A., 1997, Proterozoic sutures and terranes in the southeastern Baltic Shield interpreted from BABEL deep seismic data: Tectonophysics, v. 270, pp. 259-277.

Amundsen, H.E.F. et al., 2002. Reading the LIPs of Iceland and Mauritius, in Jamtveit, B. and Amundsen, H.E.F., eds, 15th Kongsberg Seminar, May 8-10, Kongsberg, Norway.

Anderson, D.L., 2005, Scoring hotspots: the plume and plate paradigms, in Foulger, G.R., Natland, J.H., Presnall, D.C., and Anderson, D.L., eds, Plates, plumes, and paradigms: Geological Society of America, Special Paper 388, Boulder, CO, USA, pp. 31-54.

Angenheister, G., et al., 1980, Reykjanes Ridge Iceland Seismic Experiment (RRISP 77): Journal of Geophysics, v.47, pp. 228-238.

Artemieva, I.M., 2006, Global $1^{\circ} \times 1^{\circ}$ thermal model TC1 for the continental lithosphere: Implications for lithosphere secular evolution: Tectonophysics, v. 416, pp. 245-277. See also: www.lithosphere.info.

Artemieva, I.M., 2007, Dynamic topography of the East European Craton: Shedding light upon the lithospheric structure, composition and mantle dynamics: Global Planetary Change, v. 58, pp. 411-434, doi 10.1016/ j.gloplacha. 2007.02.013.

Artemieva, I.M., Thybo, H., and Kaban, M.K., 2006, Deep Europe today: Geophysical synthesis of the upper mantle structure and lithospheric processes over $3.5 \mathrm{Ga}$, in: Gee, D. and Stephenson, R., eds, European Lithosphere Dynamics: Geological Society London Sp. Publ., v. 32, pp. 11-41.

Artemieva, I.M., 2003, Lithospheric structure, composition, and thermal regime of the East European craton: Implications for the subsidence of the Russian Platform: Earth and Planetary Science Letters, v. 213, pp. 429-444.

Artemieva, I.M. and Mooney, W.D., 2001, Thermal structure and evolution of Precambrian lithosphere: A global study: Journal Geophysical Research, v.106, pp. 16387-16414.

Baadsgaard, H., 1973, U-Th-Pb dates on zircons from early Precambrian Amitsoq gneisses, Godthaab-district, West Greenland: Earth and Planetary Science Letters, v. 19, pp. 22-28.

BABEL Working Group, 1990, Evidence for early Proterozoic plate tectonics from seismic reflection profiles in the Baltic Shield: Nature, v. 348, no. 6296, pp. 34-38.

Ballard, S. and Pollack, H.N., 1987, Diversion of heat by Archean cratons: a model for southern Africa: Earth and Planetary Science Letters, v. 85, pp. 253-264.

Bamber, J.L., Layberry, R.L., and Gogineni, S., 2001, A new ice thickness and bed data set for the Greenland ice sheet 1 . Measurement, data reduction, and errors: Journal Geophysical Research, v. 106, pp. 33773-33780.

Beach, A., 1986, A Deep Seismic-Reflection Profile Across the Northern North-Sea: Nature, V. 323, P. 53.

Bijwaard, H., Spakman, W., 1999, Tomographic evidence for a narrow whole mantle plume below Iceland: Earth Planetary Science Letters, v.166 (3-4), pp. 121-126.

Bjarnason, I.T., Menke, W., and Flovenz, O.G., 1993, Tomographic image of the Mid-Atlantic plate boundary in southwestern Iceland: Journal Geophysical Research, v.98, pp. 6607-6622.

Bjarnason, I.T., Menke, W., and Flovenz, O.G., 1994, Tomographic image of the Mid-Atlantic plate boundary in southwestern Iceland - Reply: Journal Geophysical Research, v.99, pp. 17915-17917.

Björnsson, A., Eysteinsson, H., and Beblo, M., 2005, Crustal formation and magma genesis beneath Iceland: Magnetotelluric constraints, in Foulger, G.R., Natland, J.H., Presnall, D.C., and Anderson, D.L., eds, Plates, plumes, and paradigms: Geological Society of America, Special Paper 388, Boulder, CO, USA, pp. 665-686.

Blundell, D., Freeman, R., and Mueller, S., eds., 1992, A continent revealed. The European Geotraverse: Cambridge University Press, 275 pp.

Bott, M.H.P. and Gunnarsson, K., 1980, Crustal structure of the IcelandFaeroe ridge: Journal of Geophysics, v. 47, pp. 221-227.

Boutilier, R.R. and Keen, C.E., 1999, Small-scale convection and divergent plate boundaries: Journal Geophysical Research, v. 104, pp. 73897403.

Bruneton, M, et al., 2004, Complex lithospheric structure under the central Baltic Shield from surface wave tomography: Journal Geophysical Research, v. 109, Art. No. B10303.

Calcagnile, G., 1991, Deep structure of Fennoscandia from fundamental and higher mode dispersion of Rayleigh waves: Tectonophysics, v. 195, pp. 139-149. 
Chian, D.P. and Louden, K., 1992, The Structure of Archean-Ketilidian Crust Along the Continental-Shelf of Southwestern Greenland from a Seismic Refraction Profile: Canadian Journal Earth Sciences, v. 29, pp. 301-313.

Chauvel, C. and Hemond, C., 2002, Melting of a complete section of recycled oceanic crust: Trace element and $\mathrm{Pb}$ isotopic evidence from Iceland: Geochemistry, Geophysics, Geosystems, v.1, 10.1029/ 1999GC000002.

Courtillot V., Davaille A., Besse J., and Stock J., 2003. Three distinct types of hotspots in the Earth's mantle: Earth and Planetary Science Letters, 205, 295-308.

Dahl-Jensen, T., Thybo, H., Hopper, J., and Rosing, M., 1998, Crustal structure at the SE Greenland margin from wide-angle and normal incidence seismic data: Tectonophysics, v. 288, pp. 191-198.

Dahl-Jensen T., Larsen T.B., Woelbern I., et al., 2003:. Depth to Moho in Greenland: receiver-function analysis suggests two Proterozoic blocks in Greenland: Earth and Planetary Science Letters, v. 205, pp. 379-393.

Darbyshire, F.A., White, R.S., and Priestley, K.F., 2000, Structure of the crust and uppermost mantle of Iceland from a combined seismic and gravity study: Earth and Planetary Science Letters, v. 181, pp. 409-428.

Darbyshire, F.A. et al., 2004, A first detailed look at the Greenland lithosphere and upper mantle, using Rayleigh wave tomography: Geophysical Journal International, v. 158, pp. 267-286.

Davaille, A., and J. Vatteville, 2005, On the transient nature of mantle plumes: Geophysical Research Letters, v. 32, L14309, doi:10.1029/ 2005 GL023029.

Eysteinsson, H. and Gunmarsson, K., 1995, Maps of gravity, bathymetry, and magnetics for Iceland and surroundings, report no. OS-95055/JHD07: Reykjavik, National Energy Authority, 39 pp.

Fedorova, T., Jacoby, W.R., and Wallner, H., 2005, Crust-mantle transition and Moho model for Iceland and surroundings from seismic, topography, and gravity data: Tectonophysics, v. 396, pp. 119-140.

Forsyth, D.A., Morel, A.L., Huissier, P., Asudeh, I., Green, A.G., 1986, Alpha Ridge and Iceland: products of the same plume? Journal of Geodynamics, v. 6, pp. 197-214.

Foulger, G.R., Anderson D.L., 2005, A cool model for the Iceland hotspot: Journal Volcanology Geothermal Research, v. 141, pp. 1-22. See also: www.mantleplumes.org.

Foulger, G.R., Natland, J.H., and Anderson, D.L., 2005, Genesis of the Iceland melt anomaly by plate tectonic processes, in Foulger, G.R., Natland, J.H., Presnall, D.C., and Anderson, D.L., eds, Plates, plumes, and paradigms: Geological Society Of America, Special Paper 388, Boulder, CO, USA, pp. 595-626.

Gaal, R. and Gorbatschev, R., 1987, An outline of the Precambrian evolution of the Baltic shield: Precambrian Research, v. 35, pp. 15-52.

Gebrande, H., Miller H., and Einarsson, P., 1980, Seismic structure of Iceland along RRISP-Profile I: Journal of Geophysics, v. 47, pp. 239-249.

Grand, S.P., 2002, Mantle shear-wave tomography and the fate of subducted slabs: Phil. Trans. Royal Soc. London Series A, v. 360, pp. 2475-2491.

Holbrook, W.S., et al., 2001, Mantle thermal structure and active upwelling during continental breakup in the North Atlantic: Earth and Planetary Science Letters, v. 190, pp. 251-266.

Hyvonen, T., Tiira, T., Korja A., et al. 2007, A tomographic crustal velocity model of the central Fennoscandian Shield: Geophysical Journal International, v. 168, pp. 1210-1226.

Jackson, I., 2000, Laboratory measurement of seismic wave dispersion and attenuation: recent progress: Geophysical Monograph, v. 117, pp. 265-289.

Jaupart, C. and Mareschal, J.-C., 1999, Thermal structure and thickness of continental roots: Lithos, v. 48, pp. 93-114.

Kaban, M.K., Flovenz, O.G., and Palmason, G., 2002, Nature of the crustmantle transition zone and the thermal state of the upper mantle beneath Iceland from gravity modeling: Geophysical Journal International, v. 149, pp. 281-299.

Kaban, M.K., Schwintzer, P., Artemieva, I.M., and Mooney, W.D., 2003, Density of continental roots: compositional and thermal effects: Earth and Planetary Science Letters, v. 209, pp. 53-69.

Kalsbeek, F., 1993, Geochronology of Archean and Proterozoic Events in the Ammassalik Area, South-East Greenland, and Comparisons with the Lewisian of Scotland and the Nagssugtoqidian of West Greenland: Precambrian Research, v. 62, pp. 239-270.

Kelly, A., England, R.W., and Maguire, P.K.H., 2007, A crustal seismic velocity model for the UK, Ireland and surrounding seas: Geophysical Journal International, v. 171, pp. 1172-1184.

Kennett, B.L.N., Engdahl, E.R, and Buland, R. 1995,. Constraints on seismic velocities in the Earth from traveltimes: Geophysical Journal International, v. 122, pp. 108-124.
Kodaira, S., Mjelde, R., Gunnarsson, K., Shiobara, H., and Shimamura, H., 1998, Structure of the Jan Mayen microcontinent and implications for its evolution: Geophysical Journal International, v. 132, pp. 383-400.

Korenaga, J. and Kelemen, P.B., 2000, Major element heterogeneity in the mantle source of the North Atlantic igneous province: Earth and Planetary Science Letters, v.184, pp. 251-268.

Korja, A., Korja, T., Luosto, U., and Heikkinen, P., 1993, Seismic and geoelectric evidence for collisional and extensional events in the Fennoscandian shield - implications for Precambrian crustal evolution: Tectonophysics, v. 219, pp. 129-152.

Korsman, K., Korja, T., Pajunen, M., Virransalo, P, and GGT/SVEKA WG, 1999, The GGT/SVEKA transect: structure and evolution of the continental crust in the Paleoproterozoic Svecofennian orogen in Finland: International Geological Review, v. 41, pp. 287-333.

Kukkonen, I. T. \& Peltonen, P., 1999, Xenolith-controlled geotherm for the central Fennoscandian Shield: implications for lithosphere-asthenosphere relations: Tectonophysics, v. 304, pp. 301-315.

Kumar, P., et al., 2005, The Lithosphere-Asthenosphere Boundary in the North West Atlantic region: Earth and Planetary Science Letters, v. 236, pp. 249-257.

Kumar P., Kind R., Priestley K., and Dahl-Jensen T., 2007, Crustal structure of Iceland and Greenland from receiver function studies: Journal Geophysical Research, v. 112, B03301, doi: 10.1029/2005JB003991.

Lawver, L.A. and Müller, D.R., 1994, Iceland "hotspot" track: Geology, v. 22, pp. 311-314

Lee, C.T.A., 2003, Compositional variation of density and seismic velocities in natural peridotites at STP conditions: Implications for seismic imaging of compositional heterogeneities in the upper mantle: Journal Geophysical Research, v. 108 (B9), art. no. 2441.

Lundin, E.R. and Dore, A.G., 2005, Fixity of the Iceland "hotspot" on the Mid-Atlantic Ridge: Observational evidence, mechanisms, and implications for Atlantic volcanic margins, in Foulger, G.R., Natland, J.H., Presnall, D.C., and Anderson, D.L., eds, Plates, plumes, and paradigms: Geological Society of America, Special Paper 388, Boulder, CO, USA, pp. 627-652.

Lyngsie, S.B., and Thybo, H., 2007, A new tectonic model for the Laurentia-Avalonia-Baltica sutures in the North Sea: A case study along MONA LISA profile 3: Tectonophysics, v. 429, pp. 201-227, doi:10.1016/ j.tecto.2006.09.017.

McKenzie, D., Stracke, A., et al., 2004, Source enrichment process responsible for isotopic anomalies in oceanic island basalts: Geochimica et Cosmochimica Acta, v. 68, pp. 2699-2724.

Menke, W. and Levin, V., 1994, Cold crust in a hot spot: Geophysical Research Letters, v.21, pp. 1967-1970.

MONA LISA Working Group, 1997, Deep seismic investigations of the lithosphere in the southeastern North Sea: Tectonophysics, v. 269, pp. $1-19$.

NOAA National Geophysical Data Center, 2001, 2 Minute Gridded Global Relief Data (ETOPO2): www.ngdc.noaa.gov/mgg/fliers/01mgg04.html. NGDC, Boulder, Colorado.

Nutman, A.P., Friend, C.R.L., Kinny, P.D., and McGregor, V.R., 1993, Anatomy of an Early Archean gneiss complex: 3900 to 3600 Ma crustal evolution in southern West Greenland: Geology, v. 21, pp. 415-418.

Olesen, O. et al., 2002, Bridging the gap between the onshore and offshore geology in Nordland, northern Norway: Norwegian Journal of Geology, v. 82, pp. 243-262.

Olsen, P., ed, 1995, Continental rifts: Evolution, structure, tectonics: Developments in Geotectonics, v.25, Elsevier, 466 pp.

Olsson, S., Roberts, R.G., and Bodvarsson, R., 2007, Analysis of waves converted from $\mathrm{S}$ to $\mathrm{P}$ in the upper mantle beneath the Baltic Shield: Earth and Planetary Science Letters, v. 257, pp. 37-46.

Palmason, G., 1971, Crustal structure of Iceland from explosion seismology: Societas Scientiarum Islandica, v. 40, p.187.

Peltonen, P. and Brugmann, G., 2006, Origin of layered continental mantle (Karelian craton, Finland): Geochemical and Re-Os isotope constraints: Lithos, v. 89, pp. 405-423.

Ramberg, I.B., and Smithson, S.B., 1975, Geophysical interpretation of crustal structure along southeastern coast of Norway and Skagerrak: Geological Society of America Bulletin, v. 86, pp. 769-774.

Ritsema, J., and Allen. R., 2003, The elusive mantle plume: Earth and Planetary Science Letters, v. 207, pp. 1-12.

Raum, T., Mjelde, R., Digranes, P., et al., 2002, Crustal structure of the southern part of the Vøring Basin, mid-Norway margin, from wideangle seismic and gravity data: Tectonophysics, v, 355, pp. 99-126.

Sato, H., Sacks, I.S., and Murase, T., 1989, The use of laboratory velocity data for estimating temperature and partial melt fraction in the low- 
velocity zone: comparison with heat flow and electrical studies: Journal Geophysical Research, v. 94, pp. 5689-5704.

Schiellerup, H., 1995, Generation and equilibration of olivine tholeiites in the northern rift zone of Iceland. A petrogenetic study of the Blafjall table mountain: Journal Volcanology of and Geothermal Research, v. 65, pp. 161-179.

Schmeling, H., 1985, Partial melt below Iceland: A combined interpretation of seismic and conductivity data: Journal Geophysical Research, v. 90, pp. 10105-10116.

Shapiro, N.M., and Ritzwoller, M.H. 2002, Monte-Carlo inversion for a global shear velocity model of the crust and upper mantle: Geophysical Journal International, v. 151, pp. 1-18.

Staples, R.K., et al, 1997, Faeroe-Iceland ridge experiment 1. Crustal structure of northeastern Iceland: Journal Geophysical Research, v. 102, pp. 7849-7866.

Stein, C. and Stein, S., 2003, Sea floor heat flow near Iceland and implications for a mantle plume: Astronomy and Geophysics, v. 44, pp. $1.8-1.10$.

Svenningsen, L., N. Balling, B. H. Jacobsen, R. Kind, K. Wylegalla and J. Schweitzer, 2007, Crustal root beneath the highlands of southern Norway resolved by teleseismic receiver functions: Geophysical Journal International, v. 170, pp. 1129-1138 doi: 10.1111/j.1365-246X.2007. 03402.x.

Irina Artemieva is Associate Professor at University of Copenhagen, Denmark, where she received her Dr. Science degree in 2007. She received her M.S. in Physics in 1984 from Lomonosov Moscow State University and her Ph.D. in 1987 from Institute of Physics of the Earth, Moscow. Since 1999 she has worked as researcher at Uppsala and Strasbourg Universities, at USGS (Menlo Park, CA), and was Science Coordinator of ESF program EUROPROBE. She is Fellow of Royal

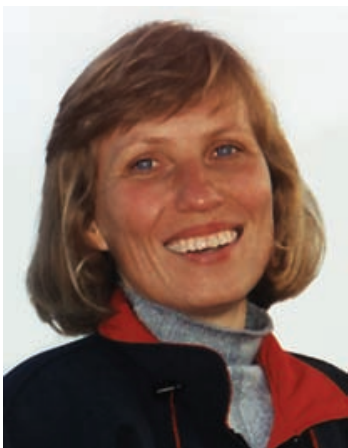
Astronomical Society, London and member of Academia Europaea. She is member of the Natural Sciences Research Council in Sweden and associate editor of Tectonophysics and J. of Geodynamics.
Thybo, H., 1997, Geophysical characteristics of the Tornquist Fan area, northwest TESZ: Indication of Late Carboniferous to Early Permian dextral transtension: Geological Magazine, v. 134, pp. 597-606.

Thybo, H., 2006, The heterogeneous Upper Mantle Low Velocity Zone: Tectonophysics, v. 416, pp. 53-79.

Thybo, H. and Perchuc, E., 1997, The seismic $8^{\circ}$ Discontinuity and Partial Melting in Continental Mantle: Science, v. 275, pp. 1626-1629.

Thybo, H., Pharaoh, T., and Guterch, A., eds, 2002, The Trans European Suture Zone II: Tectonophysics, v. 360, 378 pp.

Tiira, T., Hyvonen, T., Komminaho, K., Korja, A., Heikkinen, P., 2006 3-D inversion of Moho discontinuity using wide-angle reflections in the Baltic Shield (abs): European Union of Geosciences, Abstracts, EGU06-A-06893.

Tsikalas, F, Eldholm, O, and Faleide, JI, 2005, Crustal structure of the Lofoten-Vesterdlen continental margin, off Norway: Tectonophysics, v. 404, pp. $151-174$

Vinnik, LP, Foulger, GR, and Du Z, 2005, Seismic boundaries in the mantle beneath Iceland: a new constraint on temperature: Geophysical Journal International, v. 160, pp. 533-538.

Zielhuis, A. and Nolet, G., 1994, Deep seismic expression of an ancient plate boundary in Europe: Science, v. 265, pp. 79-81.

Hans Thybo is Professor of Geophysics at University of Copenhagen, Denmark. He received his M.Sc. in Physics and Mathematics in 1982 and the Ph.D. in Geology in 1987 from University of Aarhus, Denmark. He is member of the Royal Danish Academy of Sciences (Presidium member) and Academia Europaea, Fellow of Royal Astronomical Society, London, and national representative to International Council of Scientific Unions. Hans Thybo is General Secretary of European Geosciences Union, member of board of Faculty of Mathematics and Natural Sciences, University of Oslo, and the Natural Sciences Research Councils in Denmark and Sweden (NT-C), and Editor-in-Chief of Tectonophysics.

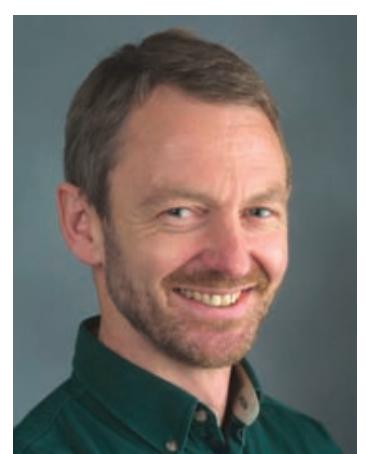

